Santa Clara University

Scholar Commons

English

College of Arts \& Sciences

$10-30-2018$

\title{
Supporting First-Generation Students' Adjustment to College With High-Impact Practices
}

Theresa Conefrey

Santa Clara University, tconefrey@scu.edu

Follow this and additional works at: https://scholarcommons.scu.edu/engl

Part of the English Language and Literature Commons

\section{Recommended Citation}

Conefrey, T. (2018). Supporting First-Generation Students' Adjustment to College With High-Impact Practices. Journal of College Student Retention: Research, Theory \& Practice, 1521025118807402. https://doi.org/10.1177/1521025118807402

The final publication is available at SAGE via https://doi.org/10.1177/1521025118807402.

This Article is brought to you for free and open access by the College of Arts \& Sciences at Scholar Commons. It has been accepted for inclusion in English by an authorized administrator of Scholar Commons. For more information, please contact rscroggin@scu.edu. 


\begin{abstract}
This qualitative case study describes some of the issues faced by incoming first-generation college students at a private, four-year institution in the north-west. Using constructs drawn from social cognitive theory and social cognitive career theory, it explores how high-impact practices such as learning communities, writing-intensive courses and ePortfolios might impact first-generation students' adjustment during their first year of college. The findings of the research on students' writing in their first-year composition course suggest that the cumulative impact of engaging in multiple high-impact practices improves students' literacy and study skills. Additionally, these educational practices appear to increase students' self-appraisal of their academic abilities in general and their institutional commitment. As a consequence of their increased self-efficacy and engagement, this study suggests that students are more likely to experience better academic outcomes, leading them to persist in their studies and be retained after their first year at college.
\end{abstract}

\title{
Keywords
}

First-generation college student, high-impact practices, ePortfolios, social cognitive theory, social cognitive career theory 
The importance of degree-completion for students' future employability is widely acknowledged as is the importance of retention for higher education institutions. Yet, while more students are starting college degree programs, attrition rates remain high, especially for first-generation college students (Cataldi, Bennett, \& Chen, 2018; Ingels et al., 2014; Lauff \& Ingels, 2015; Pratt, Harwood, Cavazos, \& Ditzfeld, 2017; Redford \& Hoyer, 2017; Seidman, 2012). Adopting a qualitative case-study approach (Huberman \& Miles, 1994; Stake, 2000), this study explores the role of high-impact practices (HIPs) in improving engagement, and academic outcomes for first-generation students at a private, four-year college in the north-west. Social cognitive theory and social cognitive career theory are used as frameworks to account for the beneficial effects of the HIPs in promoting students' adjustment and engagement during their first quarter at college and improving their retention and overall graduation rates. This qualitative case study is part of a larger ongoing research project on the experiences of firstgenerations students in higher education, responding to the continued call for more research on how to support this vulnerable student population, particularly at four-year colleges, where they are most under-represented (Stebleton, Soria, \& Huesman, 2014; Wilbur \& Roscigno, 2016). The findings reinforce the importance of a smooth transition from high-school to college for improving first year retention. A goal of this study, and the larger ongoing research project that it is part of, is to offer suggestions for promoting successful adjustment, which might be adopted at other similar institutions.

\section{First-Generation College Students}

For the purpose of this study, first-generation students are defined as those whose college application indicates that neither parent has obtained a college degree. First-generation students often differ from continuing-generation students in terms of ethnic demographics, socio- 
economic status and academic preparedness, factors which converge to negatively influence their degree completion rates. For example, using data from the 2002 NCES study and the 2004/09 Beginning Postsecondary Students Longitudinal Study, Cataldi, Bennett and Chen (2018) found that three years after beginning higher-education, 48 percent of first-generation students were persisting in their programs compared to 67 percent for continuing-generation students.

Once first-generation college students have overcome significant hurdles to begin their college education, they face unique challenges in successfully completing their degree programs, leading some first-generation students to question whether they belong in college. Unlike the "helicopter" parents of their continuing-generation peers, parents of first-generation students may lack familiarity with typical middle-class norms of college campuses and will be less able to support their children through the admissions process and transition from high school to college. Other issues identified as negatively impacting college adjustment include poorer academic preparation, internalization of negative stereotypes, less awareness of information about colleges and funding opportunities, ongoing financial concerns, culture shock, low self-esteem, and under-developed study and time-management skills (Banks-Santilli, 2014; Gibbons, Rhinehart, \& Hardin, 2016; Hamilton, 2016; Ingels et al., 2014; Irlbeck, Adams, Akers, Burris, \& Jones, 2014; Lawless, 2009; Nichols \& Islas, 2016; Pascarella, Pierson, \& Wolniak, 2004; Perna, 2015; Redford \& Hoyer, 2017; Wilbur \& Roscigno, 2016). Further confounding their problems, research suggests that first-generation college students are less likely than continuing-generation students to use on-campus student support systems (Gonzales, Brammer, \& Sawilowsky, 2015; Storlie, Mostade, \& Duenyas, 2016). As a result of these multifarious issues, first-generation students may experience more barriers, fewer supports, a weaker sense of engagement and 
belonging and decide to leave college rather than continue on to their sophomore year (Martin, 2017; Stebleton et al., 2014).

\section{High-Impact Practices}

An approach taken by universities to encourage engagement and improve retention of all students has been the implementation of high-impact practices (HIPs), institutionally-structured experiences and activities that deepen learning, and increase student engagement. According to the Association of American Colleges and Universities, which strongly endorses these practices, they include the following: first year seminars and experiences, common intellectual experiences (core curriculum), learning communities, writing-intensive courses, collaborative assignments and projects, undergraduate research, diversity/global learning, service learning or community-based learning, internships, capstone courses and projects, and ePortfolios. Research suggests that these practices, which have proven particularly beneficial for those who are most disadvantaged, help students compensate for their lack of cultural capital (Bourdieu, 1986), mitigate gaps in their academic preparedness and improve their engagement and sense of belonging (Eynon \& Gambino, 2016; Kuh, 2008).

HIPs such as Learning communities (LCs), first-year seminars, writing-intensive courses and common intellectual experiences are being increasingly adopted by institutions to support incoming first-year students. In typical LCs, students take two or more linked courses such as those noted above as a cohort and work closely with one another and their instructors and advisors. LCs may also be linked to residence halls and organized around broad themes, in which case they are known as Residential Learning Communities (RLCs). ePortfolio usage is also becoming more prevalent as a substantial body of research exists supporting the effectiveness of this tool in promoting student reflection and enhancing learning in a wide variety 
of institution types and for all student populations, particularly those that are disadvantaged (Eynon \& Gambino, 2016; Light, Chen, \& Ittelson, 2012; Reynolds, Patton, \& Rhodes, 2014). HIPs appear to work synergistically and their benefits are thought to be cumulative (Conefrey, 2017; Hubert, Pickavance, \& Hyberger, 2015; Kuh, O'Donnell, \& Reed, 2013; Tukibayeva \& Gonyea, 2014; Watson, Kuh, Rhodes, Light, \& Chen, 2016). Unfortunately, without institutional support and sufficient encouragement, incoming first-generation students tend not to experience as many HIPs as continuing-generation students (Kuh, 2008; Kuh et al., 2013).

\section{Social Cognitive Theory and Social Cognitive Career Theory}

The beneficial changes that first-generation students articulate in their ePortfolios as a result of their participation in multiple HIPs can be accounted for by two well-established, related behavioral change models, Social Cognitive Theory (SCT) and Social Cognitive Career Theory (SCCT). SCT (Bandura, 1986), which attempts to explain how people acquire, maintain, and change their behaviors, assumes that learning is both cognitive and social and that it takes place in a social context involving a reciprocal and constantly-changing interplay of individuals, their environment and their behavior or "triadic causal reciprocality" (Bandura, 1986, p. 25). Central to this theory are the constructs self-efficacy, outcome expectations and goals, which are also posited to be in dynamic interaction with one another (Bandura, 1999). The reciprocal nature of these variables suggests that self-efficacy influences behaviors and environments, and is influenced by them and that both impact self-efficacy. SCT, which suggests that the individual, the environment and the behavior are continually influencing other, has been applied to a wide variety of situations involving the interrelation of social factors, individual thought and behavior. 
SCT has been used extensively in explaining educational and career choice and development. It has also been extended by Lent, Brown and Hackett (1994; 2000; 2002) and Lent and Brown (2002), and others to become known as SCCT (Ireland \& Lent, 2018; Lent, Ezeofor, Morrison, Penn, \& Ireland, ; Lent et al., 2015; Lent et al., 2016; Lent et al., 1994). SCT and SCCT provide a useful framework for understanding the adjustment of first-generation students to college. Using this framework, the impact of HIPs on students' adjustment to college, can be evaluated in terms of how they change students' self-appraisals of efficacy, their outcomes expectations and the goals they set for themselves. According to SCT and SCCT, students with greater self-efficacy and more positive outcome expectations will tend to set more challenging goals for themselves and persist in the face of obstacles (academic and social) to complete their degrees.

\section{Context of the study}

This qualitative case-study explores the role of high-impact practices (HIPs) in improving engagement, and academic outcomes for first-generation students at a private, four-year college in northern California, which will be known as Bay University. The overarching research question was: How do HIPs impact engagement and academic outcomes for first-generation students? The LC that is the focus of this case study is dedicated to the unique needs of firstgeneration students. It comprises first-generation students who take common courses together and peer mentors, faculty members, and advisors, who help ease their transition into campus life. Apart from the first-year seminar, first-year writing and other common intellectual experiences that they participate in as a cohort during their first year in college, first-generation students may also participate in additional HIPs along with their continuing-generation peers such as participating in an RLC and engaging in community-based learning and undergraduate research. 
Engaging in these HIPs leads to the development of relationships with faculty, counsellors and peers, which support students' academic and social acculturation by supplying useful information, values and perspectives, and has a compensatory effect for the cultural capital that they are not able to acquire from family.

Since the outcome of their first college classes informs students' decisions on whether or not to persist into their second year, this study focuses on first-generation students' work in one of their first college courses, first-year composition, which like mathematics is often viewed as a gateway course (Adelman, 2006; Callahan \& Belcheir, 2017; Gonzales et al., 2015). All incoming students are enrolled in this required two-sequence course during their first-year of study. This two-sequence course is taken as a cohort, with each section comprising an instructor and a peer educator and about 19 students. Each of the four sections in the LC uses a common syllabus and requires students to collect select samples of their work for inclusion in an online portfolio, or ePortfolio. For their culminating assignment, students are tasked with using their ePortfolios to demonstrate that they have met the course learning outcomes. Common assignment prompts are: "Create an ePortfolio that shows your development as a critical reader" or "Make an argument about the most important habits and strategies you rely upon as reader/writer, as well as provide evidence that illustrates these habits and strategies." The digital affordances of this educational technology enable students to upload multiple drafts of their essays with feedback from peers and instructors to their portfolios and to include screenshots, videos, audio, graphics, photos and other multimedia. Since most students have little difficulty meeting the learning outcomes of this college writing course to obtain a passing grade, the aim of this qualitative case-study was not to evaluate students' progress objectively. Instead, the goal of this qualitative study was to provide a rich account of students' perceptions of progress in this 
and other first-year courses. Nevertheless, as will be discussed later, students' self-efficacy has been shown to correlate with actual academic gains in grades.

\section{Method}

Participants in this case study were solicited by email from the 2015-2016 and 2017-2018 cohorts of the first-generation LC. According to institutional reports at the time of the study, the LC admitted about 60 students each year, representing about 5 percent of incoming students and 50 percent of all first-generation students. Those who agreed to participate (14 women and 11 men), signed an IRB-approved consent letter granting access to their ePortfolios, the final assignment in the first of their two-sequence first-year English course called Critical Thinking and Writing (CTW), which was taken during their first quarter of college and focused on preparing them for college-level reading and writing. Each course section followed a common syllabus, but assignments varied slightly, with the ePortfolio being assigned either 15 percent or 20 percent of the final grade depending on the section. Analyzing ePortfolios from multiple sections was thought to offer a richer understanding and to increase reliability (Huberman \& Miles, 1994; Miles, Huberman, \& Saldaña, 2014). Additionally, the data corpus included copies of syllabi, readings and assignments provided by instructors and interviews with the LC director and faculty advisers to provide additional context.

Each ePortfolio was read multiple times and then the contents were transcribed and initial codes were generated using thematic analysis, a method for identifying, analyzing and reporting patterns in data (Braun \& Clarke, 2006; Clarke \& Braun, 2013). Data were initially coded and recoded inductively and then deductively, interpreting those early observations and emergent themes through the cognitive constructivist framework of SCT and SCCT constructs. In other words, the active engagement of the researcher is acknowledged insofar as the final themes did 
not simply "emerge" objectively, but rather resulted from the application of the researcher's theoretical framework in an iterative process of going back and forth between phases of data analysis as needed (Braun \& Clarke, 2006). To increase the trustworthiness of the analysis and as a check on the reliability and validity of the codes, course instructors and supervisors were consulted to provide feedback on emerging themes. While reliability and validity can be concern with qualitative studies, researchers have proposed that an important criterion for judging qualitative research is whether the accounts are meaningful, credible and capable of redirecting practice (Blakeslee, Cole, \& Conefrey, 2011; Denzin \& Lincoln, 1994; Stake, 2000).

\section{Findings}

Depending on the assignment prompt and the platform chosen, the contents of students' ePortfolios varied considerably. In all cases, thematic analysis suggested that students were integrating into their ePortfolios learning from their first-year writing course and other HIPs that they had engaged in during their first term on campus. Three themes deriving from the frameworks of SCT and SCCT were identified: (1) increased self-efficacy in literacy and study skills, (2) improved outcome expectations and (3) a reduction in perceived barriers and an increase in perceived supports. Representative examples of each category are discussed in the following sections.

\section{Increased self-efficacy in literacy and study skills}

All students articulated the perception that their reading and writing skills had improved significantly over the course of the quarter. As evidence in their ePortfolios, they made their learning visible to themselves and others by providing screen captures of excerpts from annotations on readings and essays at the beginning of the quarter and nearer the end as well as feedback from instructors. In describing subsequent improvements in literacy, students made 
frequent references to practices and study habits that had served them well in high-school but had proved inadequate for college. For many, it was a case of unlearning what they had learned such as formulaic, timed, five-paragraph essays. Such was the case for the student who wrote, "In the beginning of the year, my writing was stuck on a robotic method to follow guidelines and formats from high school." Other students commented on the common high school practices of over-highlighting and excessive note taking. One woman reflected about her successful efforts to change these habits when she realized that they would no longer work given the length and complexity of college reading materials:

Throughout high school, I was never an efficient reader. It would take me hours to read a chapter for an assignment. I would take excessive notes and highlight everything of minor importance. Coming to college, I soon came to the conclusion that there was no possible way I could read extensive articles and take notes on every last detail.

Both this student and others demonstrated their increasing metacognitive awareness and selfregulation by observing that the less they highlighted, the more they learned. Similarly, another student wrote, "In my ePortfolio, I have an array of different articles that we read from the beginning of fall quarter. From left to right, you can see a huge difference of my highlighting tendencies. There is less highlighting happening, which means I am paying more attention to what I am reading." The digital format of the Portfolio made their progress more visible because they could comment on specific screenshots of readings that they had annotated and the feedback they had received on those annotations, as well as essays they had written drawing on these notes. Describing his annotated reading assignments, one individual reflected:

I understood that I needed to change to survive in a college environment. This change began once I realized my annotations were not very helpful. I found myself annoyed at 
the fact that I was not receiving full credit for my work. Luckily, my ability to make my own thoughts coherent is something that progressed as I got better at both reading critically and annotating.

Whereas high school readings had typically lacked complexity and writing assignments had required lower-order cognitive skills such as remembering and understanding (Bloom, 1956), suddenly students found themselves required to read scholarly articles and respond to them in more complex ways. Summing up the changes over the quarter, one individual admitted: "Coming into Bay University, I knew I was not prepared for any Critical Thinking or English class because my analytic abilities were subpar." Using excerpts from his assignments, he was able to show himself and his viewers how his work had improved over the course of the term.

Student's increased confidence in their literacy and their study skills both in their composition course and their other first-year courses can be understood by referencing SCT's construct of self-efficacy. Student's perceptions of efficacy were not only influenced by comparing current and past performances but by observing others such as peers and mentors, being persuaded by others such as instructors and family, and managing their emotions such as controlling anxiety. Students' self-efficacy increased as they reflected on and assessed their abilities, set goals, evaluated their study habits and discovered more efficient learning strategies. In this way, students' self-efficacy and self-regulation were mutually reinforcing and had a positive impact on their learning outcomes.

\section{Improved outcome expectations and goals}

As a result of gains in literacy and study habits, students expressed increased optimism about their future at college. Some students commented explicitly on the value they saw in the experience of collecting and selecting artefacts and then reflecting on their significance in order 
to design their ePortfolio to effectively showcase their skills. This process appeared to lead to an increase in students' self-efficacy and metacognition as they gained insight into what they had learned, how they had learned, and the value of their learning for future goals. Some students recognized that these changes were not only beneficial for their composition course but for other courses also, "I now use what I learned about myself in all my classes. The different insights allow me to have better study habits and be more successful." Others commented on the act of reflecting itself, an integral aspect of creating the ePortfolio that they appeared to find particularly beneficial for deepening and integrating their learning. Expressing a high-level of metacognitive engagement, one individual noted:

This ePortfolio project ended up having more effects on me than I thought it would. Because of this project I have been able to identify, reflect on, and refine my different processes and habits as well as to better understand my background and influences and the important roles they've played in shaping who I am today....Being able to sit down and establish steps to follow makes for a more organized and efficient work ethic. I am able to see what steps work and what steps don't, and try different processes until I find what works best for me. Because of these reflections I have grown as a reader, writer, and student.

Underlining the importance of self-efficacy in outcomes expectations and goal setting, students articulated an awareness of how a more positive self-appraisal could offset inevitable obstacles to achieving their goals and promote increased resilience and persistence in the face of inevitable setbacks. A male remarked:

From these failures, I became brave and gained grit to follow my dreams and trust in my capability to succeed. Most importantly, it leads me to reflect on my trajectory as an 
educated literate person and brace myself for the difficulties I will encounter in the future. I acknowledge that in order succeed I must live through much trial and error but must confront these situations with courage.

\section{Reduction in perceived barriers and increase in perceived supports}

A third theme in their ePortfolios was students' perception that perceived barriers had been decreased and perceived supports increased. Those born into Spanish-speaking families and those who had immigrated to the USA commented on perceived issues with their English language skills at high school, such as the female who wrote: "I was put in a remedial English class because the counselors expected that I would have learning difficulties. I disliked being in that class because I thought that I did not belong." Other students expressed initial low selfesteem on arriving at college, such as the male who reflected: "Ever since my transition to a private institution, Loyola High School, during my second year of high school, I immediately felt as if I was not as smart, talented, or athletic as the other students. "On the other hand, as a result of being very successful in their high-schools, and a lack of realistic expectations of campus life, some students had arrived on campus over-confident in their abilities. This was true for the student who noted: "I arrived to college this year believing that high school had been my main life, and that I could officially cruise through college. I had never been more wrong in my life."

Other students reflected on how they had learned to overcome the reluctance to seek help, which is common in first-generation students. One individual wrote: “Asking for help when I was struggling was one of my weaknesses. I thought I could do everything by myself, but I could not all the time, especially when I was struggling with understanding the concepts." Later, describing the change in her behavior after having reevaluated this habit that was not serving her 
well, the same student wrote about learning to seek out multiple sources of help such as tutors at the writing center, her friends and her professor.

Some students in reflecting on the positive impact that friendships had on their reappraisals of their abilities referenced other sources of information on self-efficacy such as vicarious learning, persuasion by others and reduction in negative affect. A female commented: I was fortunate to meet Kate and saw myself in her immediately. We became fast friends; her kindness, paired with a strong work ethic, quickly made her a role model for me. I remember being in awe of how much we had in common and thankful to have such an amazing person in my life, to whom I could turn if I ever needed help. That being said, I was a little intimidated by the ease in which she balanced it all. The fact that we had so much in common allowed me to see that such success was possible, "You don't have to have everything figured out right away," she remarked gently. Such relaxed validation renewed my determination and, while it did not necessarily provide a technical formula for weathering college, was the best thing Kate could have done for me.

Others, however, noted that friends could act as both barriers and supports: On the one hand they could distract students from their attempts to study but on the other hand, they could offer feedback on assignments and supply the emotional support that students needed to cope in their new environment. Expressing this dual nature of friendships, one student commented:

The friends I have met in college have also helped my literacy improve. Thanks to them I am more focused on the tasks and am able to finish the readings and essays quicker. Although they can be a distraction at times, my friends also keep me away from other distractions. The people in the pictures below are the friends I've made in the second part 
of my life, and they have already made this place feel like I'm at home with a new family.

From accounts in students' eportfolios, it appeared that parents, who were a prominent influence on students' behaviors and attitudes, could also function as both barriers and supports. Students expressed how fortunate they were to have received emotional support from their parents, and recognized efforts by their parents to identify sources of academic information that they themselves could not supply. Additionally, students' experiences of their parents' career struggles were connected to their own motivations to succeed. A Latina student, expressing her appreciation for her mother, who did not speak English well, observed:

My mother got us into the best public school in our city and forced us to get help through programs the schools provided. My mom is my biggest motivation for being a hardworking student who does not settle for less. Although my parents could not always help me directly with my assignments, they always made sure I received help from tutors or other academic programs.

Finally, the LC, where students were able to meet other first-generation students like themselves and receive guidance from advisors and faculty who were connected to it, appears to have functioned as a significant source of support to students' adjustment. With its first-year writing, first-year seminars and other experiences taken as a cohort, it helped to mitigate many of the potential barriers to students' success. In short, students' participation in HIPs appeared to help them overcome some of the barriers to their adjustment identified earlier such as poorer academic preparation, internalization of negative stereotypes, less awareness of information about colleges and funding opportunities, culture shock, low self-esteem, reluctance to seek help and under-developed study and time-management skills. Additionally these HIPs appeared to 
increase students' engagement and sense of belonging at the institution, as well as their appraisals of efficacy, which strengthened their commitment to continuing their degree programs.

\section{Discussion}

This qualitative case study of first-generation students' adjustment to a private, four-year, liberal arts college, which takes as its data set students' writing in their ePortfolios, the culminating project of their first-year composition class, suggests that participation in this required course led to students' increased confidence in their literacy and study skills, partially compensating for their academic preparedness. Furthermore, the reflective aspect of creating the ePortfolio led to improved metacognitive awareness and self-regulated learning, which, in turn, helped students identify and clarify their academic goals and interests. Additionally, their participation in the LC for first-generation students with whom they took this course and other

first-year seminars and experiences led to an increase in their sense of belonging in the university as they were able to start building supportive networks with other first-generation students, faculty and advisers. These findings on students' perceptions of the beneficial impact of HIPs are supported by institutional reports from 2007-2014 for the LC that is the focus of this study. Whereas the average first-year retention during this period was $98 \%$ for first-generation students in the program, it was $93 \%$ for other first-generation students and $94 \%$ for all other students. Similarly, the average four-year graduation rate was $83 \%$ for first-generation in the LC, $78 \%$ for other first-generation students and $81 \%$ for all other students (Dancer, 2017).

These findings are also consistent with prior quantitative research, which showed that the greater the number of HIPs, the greater the benefit for first-generation students (Finley \& McNair, 2013). Given the use of SCT and SCCT as explanatory frameworks for understanding 
students' adjustment to college (Lent et al., 1994), it is useful to consider these findings through those lenses. Central to students' successful adjustment was their reappraisal of efficacy (Bandura, 1989; 2000; 2001). As their perceptions of self-efficacy increased, their outcomes expectations and goals changed, each positively influencing the other and strengthening their motivation. The increase in self-efficacy, reduction of negative environmental factors, and increase in perceived support offer an explanation for the beneficial impact of HIPs in improving first-generation students' adjustment.

\section{Increased confidence in their literacy and their study skills}

The finding that participation in HIPs boosted academic self-efficacy and self-regulation is important because as students adjust to the transition from high-school to college, they gain control of their own study habits and time-management. Understanding the amount of time and quality of effort required to succeed is crucial to students' acculturation and future goal setting. The act of reflecting on one's writing, an integral aspect of ePortfolio pedagogy, adds an additional cognitive load, which students are likely to resist unless required to do so and unlikely to do well unless given help with organizing their thoughts. However, when done well, reflection appears to increase their metacognition and strengthen their self-efficacy and selfregulation.

Research suggests that more metacognitively-aware students are better able to monitor and appraise their own learning and make more effective use of feedback to further improve their efficacy. Cera, Mancini and Antonietti (2013) found that high self-efficacy correlated with higher metacognitive skills. Additionally, they found that having high self-efficacy could increase self-regulation and perseverance as well as decrease learning anxiety. Prat-Sala and Redford (2010) noted a similar affective response and found that appraisals of efficacy were 
correlated with students' motivation and study habits, with students expressing higher levels of self-efficacy in reading and writing also engaging in more effective study habits. This finding supports claims from SCT (Bandura, 1996; 2000) that students' beliefs about their academic abilities affect their cognitive, motivational and affective processes and in turn are affected by them because these beliefs manage how they think, feel and behave.

Prior research also suggests a correlation between beliefs about abilities and grade achievement. The standards that students set for themselves and self-monitor and the strategies they use to motivate themselves are part of self-regulation and interact with aspects of their efficacy to impact students' actual assignment grades. Students with more confidence in their writing tend to set higher internal standards and are self-motivated to produce higher-quality writing: "Those who are assured of their capabilities intensify their efforts when they fail to achieve what they seek, and they persist until they succeed" (Zimmerman \& Bandura, 1994, p. 848). In contrast, lower-performing students have a weaker perception of self-efficacy and exercise poorer self-regulation (Zimmerman, Bandura, \& Martinez-Pons, 1992).

Newer studies continue to support this correlation. For example, Lynch (2006) found that self-efficacy and self-regulation correlated strongly with actual grades across years. Similarly, a more recent study by Prat-Sala and Redford (2012) also found that self-efficacy correlated with actual writing performance and that the relationship was even stronger for sophomores. They speculated that given the importance of literacy in successful degreecompletion, greater confidence in one's writing was likely to lead to increased motivation and persistence. This speculation was corroborated by a recent study by Callahan and Belcheir (2017), which found that a high grade in first-year composition courses was positively correlated with persistence across all majors including STEM fields and that the actual grade was more 
significant than the level of the course taken. Self-efficacy and self-regulation have also been shown to impact grades in first-year mathematics courses (Altun \& Erden, 2013) and biology across all years in college (Ridlo \& Lutfiya, 2017).

These findings on the impact of HIPs on students' first quarter also have implications for short-term interventions intended to change attitudes and behaviors. For example, Wibrowski, Matthews and Kitsantas (2017) found that a learning skills support intervention for firstgeneration students led to a positive impact on students' GPAs, retention and graduation rates. Similarly, an intervention by Betz and Schifano (2000), which used the four sources of selfefficacy information identified by Bandura (1986), in an attempt to increase women's lower selfefficacy in STEM, demonstrated a positive impact. Moreover, a more recent study by Falco and Summers (2017) of an intervention to reduce the STEM "confidence gap" in middle school girls, which introduced the girls to the concept of "growth mindset" (Dweck, 2006) also reported a positive impact on the girls' STEM self-efficacy. Growth mindset interventions of all kinds, which lead to students' viewing intelligence as malleable and being more inclined to reappraise their own abilities, have been shown to increase students' willingness to engage and to persist in difficult assignments (Paunesku et al., 2015).

\section{Increase in metacognition and self-regulated learning}

A second important finding in this study is that students' increase in confidence in literacy and study skills appears to have been amplified by the metacognitive awareness facilitated by the ePortfolio assignment. As the findings showed, students were surprised by the powerful effect of creating their ePortfolios and commented on how the process of collecting, selecting and reflecting on their work had been beneficial to their current learning, their outcome expectations and their goals for the future. ePortfolios encourage collaboration, active 
engagement and responsibility for one's own learning leading to the development of metacognitive skills, self-efficacy and self-regulated learning. Viewed through the framework of SCT, this is not so surprising since cognitive awareness and metacognition are central to selfefficacy and each positively impacts the other. Similarly, improved metacognitive skills work in tandem with self-regulation to enable students to organize learning. When self-efficacy is strong and students have a growth mindset, they choose more challenging work and persevere despite obstacles. As Tinto noted, "self-efficacy is the foundation upon which student persistence is built" (2017, p. 257). The relationship between self-efficacy and self-regulation is bidirectional in so far as greater self-efficacy leads to greater self-regulation and poor self-regulation leads to poorer self-efficacy. High levels of self-efficacy, self-regulated learning and metacognition mutually support one another leading to increased confidence and higher grades.

The idea that ePortfolios might amplify learning is supported by a growing body of ePortfolio scholarship. Singer-Freeman and Bastone (2017) tested this possibility with a growth mindset intervention on community college students in a summer research program. They found that the impact was even greater when the intervention was combined with an ePortfolio assignment than with more conventional formats. They speculate that reflection is intensified by creating the ePortfolio and that the holistic view of learning encouraged by the ePortfolio further reinforces a growth mindset over a more fixed view of learning. Similar results were found by Bowman, Lowe, Sabourin and Sweet (2016). In their study of a first-year LC program that used both digital and paper portfolios, they observed that students in all sections found the reflective aspect of the portfolio assignment valuable and that those in ePortfolios sections realized even greater gains in the course and in future goal-setting for their majors and careers. 
Additionally, a significant body of research exists suggesting that at institutions with sustained ePortfolio initiatives, student ePortfolio usage correlates with academic success, as measured by grades and retention rates. Eynon and Gambino (2016) provided evidence from 24 institutions of all types participating in the Connect 2 Learn Project of the beneficial impact of ePortfolios, when done well. Their findings suggested that ePortfolios could connect multiple HIPs imbuing them with more meaning and coherence thus enhancing their ability to promote integrative and intentional learning. In other words, ePortfolios appeared to function synergistically with other HIPs to amplify the benefits accrued by participating in individual, specific HIPs. This finding of amplification engendered by ePortfolios has led some to claim that this newly-identified HIP might be considered a "meta-HIP" (Watson et al., 2016).

Lastly, ePortfolios have an expansive and longitudinal capacity so that students can continue to work on them as they take further courses and participate in additional HIPs. In this way, they can increase intentional learning, help students clarify their goals and develop career awareness, which can further strengthen students' motivation to complete their degrees. Reflection, which is at the heart of ePortfolio pedagogy, is central to self-appraisals of present and future efficacy in and across courses, as well as in and across HIPs. As with the other HIPs, the focus in ePortfolio pedagogy on the whole student, both their academic and their personal growth appears to help students understand who they are as learners and who they want to become. Longitudinal ePortfolios can become a record of student learning and are used in some institutions for assessment purposes. The AAC\&U, for example, has long been an advocate for their usage both for enhancing student learning and for assessment purposes, asserting that they create enhanced transparency around demonstrated learning and allow student work to be used as evidence of accomplishment for employers and assessment purposes. 


\section{Increase in sense of engagement and belonging}

A third important finding of this study is that participation in multiple HIPs had a beneficial impact on students' sense of belonging at the institution and their overall academic and social engagement, which bolstered their motivation to persist. As a result of participating in multiple HIPs, students were able to build relationships with faculty, which improved their engagement and sense of belonging. This, in turn, lead to them viewing themselves as a more integral part of campus life as found in other studies (Morrow \& Ackermann, 2012; Gonzales et al., 2015; Hagerty, Lynch-Sauer, Patusky, Bouwsema, \& Collier, 1992; Katrevich \& Aruguete, 2017; Pratt et al., 2017; Tinto, 2017). This finding of engagement is important because recent studies continue to show that first-generation students tend to have less contact with faculty than their continuing generation peers and are less likely to get involved in campus social activities (Katrevich \& Aruguete, 2017)

The friendships that students were able to develop with peers as a result of the HIPs were also valuable for their academic success because according to recent research, students with close friendships and strong social networks earn higher grades during their first quarter and are more likely to persist into their second year (Martin, 2017; O'Keeffe, 2013). Similarly, McEwan (2013) found that the satisfaction students' expressed for their social networks correlated positively with their institutional commitment and that students needed a strong base of peers before being inclined to seek out other kinds of institutional support. This finding of improved social networks as a result of HIPs is encouraging because recent research continues to indicate that first-generation students experience difficulties establishing social networks (Pratt et al., 2017) and are reluctant to seek out needed institutional support (Stebleton et al., 2014).

Strategies that might be implemented at other similar institutions 
This case study suggests that in order to improve retention, four-year institutions might consider increasing first-generation students' participation in HIPs to acclimate them to the college community. Where such practices are not supported by the institution, administrators might consider implementing interventions such as summer bridge courses, growth mind-set programming, and other activities to promote faculty-student interactions. Activities such as undergraduate research, leadership or peer educator opportunities could also increase students confidence in their ability to succeed, motivate them to apply the required effort and strengthen their sense of belonging on campus. Similarly, in the absence of an ePortfolio pedagogy at their institution, instructors might offer other opportunities for students to reflect on their learning and study skills to help them improve their metacognition and self-regulation, integrate their knowledge and clarify their college goals.

\section{Limitations}

The generalizability of this study is limited because it focused on first-generation students at a single institution type, a private, four-year university in the north-west. Further research to explore student experiences at other types of institutions would be helpful. Additionally, this study is limited because the data set relies on one source of data, students writing in their English course, and includes only those students who elected to participate in the study. As this ongoing study into the lived experience of first-generation student continues, additional inputs will be added to the corpus such as questionnaires or focus groups to provide additional information on students' perceptions of progress. While the goal of this and other qualitative research is to provide rich description of students' lived experience, a mixed methods study providing quantifiable measures would also be effective.

\section{Conclusion}


This qualitative case study, which is grounded in SCT and SCCT constructs, responds to the call for more research into the retention rates of first-generation college students in four-year institutions by exploring the role of HIPs in catalyzing positive behavioral change. The findings suggest that engaging students in HIPs during their first quarter at college can have a beneficial impact on their adjustment because these practices lead to an increase in self-efficacy and sense of belonging. As self-efficacy bolsters academic success and motivation, this research and institution data on student retention suggest that increasing the number of HIPs that firstgeneration students participate such as LCs, first-year writing, and ePortfolios could be an effective way of boosting their retention and degree completion rates. This study adds to current research by suggesting that increasing the retention of first-generation students requires institutions to implement programs to address both their academic and social challenges to reduce environmental barriers and strengthen campus support networks. These findings on the importance of success in early coursework and sense of belonging further reinforce the need to attend carefully to students' performance in first-year courses and to encourage both academic and social engagement addressing the whole student. 


\section{References}

Adelman, C. (2006). The toolbox revisited: Paths to degree completion from high school through college. United States: Retrieved from https://eric.ed.gov/?ID=ED490195

Altun, S., \& Erden, M. (2013). Self-regulation based learning strategies and self-efficacy perceptions as predictors of male and female students' mathematics achievement. Procedia Social and Behavioral Sciences, 106, 2354-2364.

Bandura, A. (1986). Social foundations of thought and action. Englewood Cliffs, NJ: Prentice Hall.

Bandura, A. (1989). Human agency in social cognitive theory. American Psychologist American Psychologist, 44(9), 1175-1184.

Bandura, A. (1996). Failures in self-regulation: Energy depletion or selective disengagement? Psycinqu Psychological Inquiry, 7(1), 20-24.

Bandura, A. (1999). Social cognitive theory: An agentic perspective. Asian Journal of Social Psychology, 2(1), 21.

Bandura, A. (2000). Self-efficacy: The exercise of control. New York, NY: Freeman.

Bandura, A. (2001). Social cognitive theory: An agentic perspective. Annual Review of Psychology, 52, 1-26.

Banks-Santilli, L. (2014). First-generation college students and their pursuit of the american dream. Journal of Case Studies in Education;2014, Vol.5, P1-30, 
Betz, N. E., \& Schifano, R. S. (2000). Evaluation of an intervention to increase realistic selfefficacy and interests in college women. Journal of Vocational Behavior, 56(1), 35-52.

Blakeslee, A. M., Cole, C. M., \& Conefrey, T. (2011). Evaluating qualitative inquiry in technical and scientific communication: Toward a practical and dialogic validity. In J. Conklin, \& G. F. Hayhoe (Eds.), Qualitative research in technical communication (). New York, NY: Routledge.

Bloom, B. S.Taxonomy of educational objectives. New York, NY: McKay.

Bourdieu, P. (1986). The forms of capital. In J. Richardson (Ed.), Handbook of theory and research for the sociology of education (pp. 241-258). New York, NY: Greenwood.

Bowman, Jim, Lowe, Barbara J., Sabourin, Katie, Sweet,Catherine Salomon,. (2016). The use of ePortfolios to support metacognitive practice in a first-year writing program. International Journal of ePortfolio, 6(1), 1-22.

Braun, V., \& Clarke, V. (2006). Using thematic analysis in psychology. Qualitative Research in Psychology, 3(2), 77-101.

Callahan, J., \& Belcheir, M. (2017). Testing our assumptions: The role of first course grade and course level in mathematics and english. Journal of College Student Retention: Research, Theory \& Practice, 19(2), 161-175.

Cataldi, E. F., Bennett, C. T., \& Chen, X. (2018). First-generation students: College access, persistence, and postbachelor's outcomes. Retrieved from https://nces.ed.gov/pubs2018/2018421.pdf 
Cera, R., Mancini, M., \& Antonietti, A. (2013). Relationships between metacognition, selfefficacy and self-regulation in learning. Journal of Educational, Cultural and Psychological Studies, (7), 115-141.

Clarke, V., \& Braun, V. (2013). Teaching thematic analysis. Psychologist, 26(2), 120-123.

Conefrey, T. (2017). LEADing the way with ePortfolios in a first-generation learning community. International Journal of ePortfolio, 7(2), 161-173.

Dancer, S. L. (2017). A ten-year overview of LEAD scholars, other first-generation students, and all other students who entered SCU as first-time, first-year undergraduates in fall term of years 2007 to 2016. Unpublished internal document, Santa Clara University.

Denzin, N. K., \& Lincoln, Y. S. (1994). Handbook of qualitative research (three-volume paperback ed. ed.). Thousand Oaks, Calif. [u.a.]: Sage.

Dweck, C. S. (2006). Mindset: The new psychology of success. New York, NY: Random House.

Eynon, B., \& Gambino, L. M. (2016). High impact ePortfolio practice : A catalyst for student, faculty, and institutional learning (1st ed.). Herndon: Stylus Publishing.

Falco, L. D., \& Summers, J. J. (2017). Improving career decision self-efficacy and STEM selfefficacy in high school girls. Journal of Career Development, 1-15.

Finley, A., \& McNair, T. (2013). Assessing underserved students' engagement in high-impact practices. Washington, DC .: Association of American Colleges and Universities. 
Gibbons, M. M., Rhinehart, A., \& Hardin, E. (2016). How first-generation college students adjust to college. Journal of College Student Retention: Research, Theory \& Practice,O(0), 1-23. Retrieved from https://doi.org/10.1177/1521025116682035

Gonzales, S. M., Brammer, E. C., \& Sawilowsky, S. (2015). Belonging in the academy: Building a "Casa away from casa" for latino/a undergraduate students. Journal of Hispanic Higher Education, 14(3), 223-239.

Hagerty, B. M. K., Lynch-Sauer, J., Patusky, K. L., Bouwsema, M., \& Collier, P. (1992). Sense of belonging: A vital mental health concept. YAPNU Archives of Psychiatric Nursing, 6(3), $172-177$.

Hamilton, L. T. (2016). Parenting to a degree : How family matters for college women's success. Chicago, IL: University of Chicago Press.

Huberman, A. M., \& Miles, M. B. (1994). Data management and analysis methods. In N. K. Denzin, \& Y. S. Lincoln (Eds.), Handbook of qualitative research. (p.428-444). Thousand Oaks, Calif.]: Sage.

Hubert, D., Pickavance, J., \& Hyberger, A. (2015). Reflective E-portfolios: One HIP to rule them all? Peer Review, 17(4), 15-18.

Ingels, S. J., Pratt, D. J., Alexander, C. P., Jewell, D. M., Lauff, E., Mattox, T. L., \& Wilson, D. (2014). Education longitudinal study of 2002 (ELS:2002) third follow-up data file documentation. NCES 2014-364 National Center for Education Statistics. 
Ireland, G. W., \& Lent, R. W. (2018). Career exploration and decision-making learning experiences: A test of the career self-management model. Journal of Vocational Behavior, $106,37-47$.

Irlbeck, E., Adams, S., Akers, C., Burris, S., \& Jones, S. (2014). First generation college students: Motivations and support systems. Journal of Agricultural Education, 55(2), 154165.

Katrevich, A. V., \& Aruguete, M. S. (2017). Recognizing challenges and predicting success in first-generation university students. Journal of STEM Education: Innovations and Research, $18(2), 40-44$.

Kuh, G. D. (2008). High-impact educational practices: What they are, who has access to them, and why they matter. Washington, DC: Association of American Colleges \& Universities.

Kuh, G. D., O'Donnell, K., \& Reed, S. (2013). Ensuring quality \& taking high-impact practices to scale. Washington DC: Association of American Colleges \& Universities.

Lauff, E., \& Ingels, S. J. (2015). Education longitudinal study of 2002 (ELS:2002): A first look at the postsecondary transcripts of 2002 high school sophomores. first look. NCES 2015034 National Center for Education Statistics. Retrieved from: http://nces.ed.gov/.

Lawless, B. (2009). Guiding class consciousness in first-generation college students. In T. H. Housel, \& V. L. Harvey (Eds.), The invisibility factor (pp. 23-33). Boca Raton, Florida: Brown Walker Press. 
Lent, R. W., \& Brown, S. D. (2002). Social cognitive career theory and adult career development. (pp. 76-97). Columbus, OH, US: National Career Development Association.

Lent, R. W., Brown, S. D., \& Hackett, G. (2000). Contextual supports and barriers to career choice: A social cognitive analysis. Journal of Counseling Psychology, 47(1), 36-49.

Lent, R. W., Ezeofor, I., Morrison, M. A., Penn, L. T., \& Ireland, G. W.Applying the social cognitive model of career self-management to career exploration and decision-making. Journal of Vocational Behavior, 93, 47-57.

Lent, R. W., Miller, M. J., Smith, P. E., Watford, B. A., Hui, K., \& Lim, R. H. (2015). Social cognitive model of adjustment to engineering majors: Longitudinal test across gender and race/ethnicity. Journal of Vocational Behavior, 86, 77-85.

Lent, R. W., Miller, M. J., Smith, P. E., Watford, B. A., Lim, R. H., \& Hui, K. (2016). Social cognitive predictors of academic persistence and performance in engineering: Applicability across gender and race/ethnicity. Journal of Vocational Behavior, 94, 79-88.

Lent, R. W., Brown, S. D., \& Hackett, G. (1994). Toward a unifying social cognitive theory of career and academic interest, choice, and performance. Journal of Vocational Behavior, 45(1), 79-122.

Light, T. P., Chen, H. L., \& Ittelson, J. C. (2012). Documenting learning with ePortfolios (1st ed.). San Francisco, Calif: Jossey-Bass.

Lynch, D. J. (2006). Motivational factors, learning strategies and resource management as predictors of course grades. College Student Journal, 40(2), 423. 
Martin, J. M. (2017). It just didn't work out: Examining nonreturning students' stories about their freshman experience. Journal of College Student Retention: Research, Theory \& Practice, 19(2), 176-198.

McEwan, B. (2013). Retention and resources: An exploration of how social network resources related to university commitment. Journal of College Student Retention: Research, Theory \& Practice, 15(1), 113-128.

Miles, M. B., Huberman, A. M., \& Saldaña, J. (2014). Qualitative data analysis (3. ed.). Los Angeles, Calif. : Sage.

Morrow, J. A., \& Ackermann, M. E. (2012). Intention to persist and retention of first-year students: The importance of motivation and sense of belonging. College Student Journal, 46(3), 483-491.

Nichols, L., \& Islas, Á. (2016). Pushing and pulling emerging adults through college: College generational status and the influence of parents and others in the first year. Journal of Adolescent Research, 31(1), 59-95.

O'Keeffe, P. (2013). A sense of belonging: Improving student retention. College Student Journal, 47(4), 605-613.

Pascarella, E. T., Pierson, C. T., \& Wolniak, G. C. (2004). First-generation college students: Additional evidence on college experiences and outcomes. Journal of Higher Education, 75(3), 249-284. 
Paunesku, D., Walton, G. M., Romero, C., Smith, E. N., Yeager, D. S., \& Dweck, C. S. (2015). Mind-set interventions are a scalable treatment for academic underachievement. Psychological Science, 26(6), 784-793.

Perna, L. W. (2015). Improving college access and completion for low-income and firstgeneration students: The role of college access and success program. Retrieved from http://repository.upenn.edu/gse_pubs/301

Prat-Sala, M., \& Redford, P. (2010). The interplay between motivation, self-efficacy, and approaches to studying. British J Educational Psychology, 80, 283-305.

Prat-Sala, M., \& Redford, P. (2012). Writing essays: Does self-efficacy matter? the relationship between self-efficacy in reading and in writing and undergraduate students' performance in essay writing. Educational Psychology, 32, 9-20.

Pratt, I. S., Harwood, H. B., Cavazos, J. T., \& Ditzfeld, C. P. (2017). Should I stay or should I go? retention in first-generation college students. Journal of College Student Retention: Research, Theory \& Practice. Retrieved from https://doi.org/10.1177/1521025117690868

Redford, J., \& Hoyer, K. M. (2017). First-generation and continuing-generation college students: A comparison of high school and postsecondary experiences. stats in brief. NCES 2018-009. Jessup, MD: National Center for Education Statistics.

Reynolds, C., Patton, J., \& Rhodes, T. (2014). Leveraging the ePortfolio for integrative learning : A faculty guide to classroom practices for transforming student learning. Sterling: Stylus 
Ridlo, S., \& Lutfiya, F. (2017). The correlation between metacognition level with self-efficacy of biology education college students. Journal of Physics: Conference Series, 824, 12067. $10.1088 / 1742-6596 / 824 / 1 / 012067$

Seidman, A. (2012). College student retention (Second ed.). Lanham, Md.; 4: Rowman \& Littlefield Publishers.

Singer-Freeman, K., \& Bastone, L. (2017). Changing their mindsets: ePortfolios encourage application of concepts to the self. International Journal of ePortfolio, 7(2), 151-160.

Stake, R. E. (2000). Case studies. In N. K. Denzin, \& Y. S. Lincoln (Eds.), Handbook of qualitative research (2nd ed) (pp. 435-454). Thousand Oaks, CA: Sage.

Stebleton, M. J., Soria, K. M., \& Huesman, R. L. (2014). First-generation students' sense of belonging, mental health, and use of counseling services at public research universities. Journal of College Counseling, 17(1), 6-20.

Storlie, C. A., Mostade, S. J., \& Duenyas, D. (2016). Cultural trailblazers: Exploring the career development of latina first-generation college students. Career Development Quarterly, 64(4), 304-317.

Tinto, V. (2017). Through the eyes of students. J.Coll.Stud.Retention Res.Theory Pract.Journal of College Student Retention: Research, Theory and Practice, 19(3), 254-269.

Tukibayeva, M., \& Gonyea, R. M. (2014). High-impact practices and the first-year student. New Directions for Institutional Research, 2013(160), 19-35. 
Watson, C. E., Kuh, G. D., Rhodes, T., Light, T. P., \& Chen, H. L. (2016, ). Editorial: ePortfolios - the eleventh high impact practice. International Journal of ePortfolio

Wibrowski, C. R., Matthews, W. K., \& Kitsantas, A. (2017). The role of a skills learning support program on first-generation college students' self-regulation, motivation, and academic achievement: A longitudinal study. Journal of College Student Retention: Research, Theory \& Practice, 19(3), 317-332.

Wilbur, T. G., \& Roscigno, V. J. (2016). First-generation disadvantage and college enrollment/completion. Socius: Sociological Research for a Dynamic World, 2(1). Retrieved from http://journals.sagepub.com/doi/full/10.1177/2378023116664351

Zimmerman, B. J., Bandura, A., \& Martinez-Pons, M. (1992). Self-motivation for academic attainment: The role of self-efficacy beliefs and personal goal setting. American Educational Research Journal American Educational Research Journal, 29(3), 663-676.

Zimmerman, B. J., \& Bandura, A. (1994). Impact of self-regulatory influences on writing course attainment. American Educational Research Journal American Educational Research Journal, 31(4). 